\title{
ANALISIS BUTIR SOAL UJIAN AKHIR SEKOLAH
}

\section{ANALYZING THE QUESTIONS OF THE SCHOOL FINAL EXAMINATION}

\author{
Sitti Mania1), Fitriani'2), Ahmad Farham Majid'3), Nidya Nina Ichiana4), Andi Ika \\ Prasasti Abrar ${ }^{5}$ ) \\ 1,2,3,4,5)Fakultas Tarbiyah dan Keguruan Universitas Islam Negeri Alauddin Makassar \\ sitti.mania@uin-alauddin.ac.id ${ }^{1}$, fitriani@gmail.com ${ }^{2}$, ahmad.farham@uin-alauddin.ac.id $^{3)}$, \\ nidyanina.ichiana@uin-alauddin.ac.id ${ }^{4}$, ika.prasastiabrar@uin-alauddin.ac.id $^{5)}$
}

\begin{abstract}
Abstrak
Penelitian ini bertujuan untuk mengetahui kualitas butir soal Ujian Akhir Sekolah (UAS) mata pelajaran matematika. Bentuk penelitian yang digunakan dalam penelitian ini adalah penelitian deskriptif kuantitatif. Penelitian ini bersifat evaluasi yang melibatkan 159 siswa SMAN 1 Pitumpanua. Instrumen yang digunakan dalam penelitian ini adalah pengumpulan data melalui teknik dokumentasi. Analisis terhadap data butir soal dilakukan dengan menggunakan program Anates. Hasil penelitian menunjukkan bahwa 15\% soal pada kategori baik, $67 \%$ soal pada kategori cukup baik, dan $18 \%$ soal pada kategori tidak baik. Jadi, dapat disimpulkan bahwa butir-butir soal tersebut sudah layak untuk digunakan dalam ujian akhir sekolah. Manfaat yang dapat diperoleh dari hasil penelitian ini adalah sebaiknya senantiasa menyiapkan soal cadangan untuk menggantikan soal dengan kategori tidak baik, revisi dapat dilakukan terhadap soal dengan kategori cukup baik untuk selanjutnya dapat digunakan kembali, dan soal dengan kategori baik dapat dimasukkan ke bank soal.
\end{abstract}

Kata Kunci: analisis, butir soal, program anates

\begin{abstract}
This study aims to determine the quality of the school final exam questions in mathematics. The research form used in this study is descriptive quantitative research. This research is an evaluation that involves 159 students of SMAN 1 Pitumpanua. The instrument used in this study was data collection through documentation techniques. Analysis of the item data was carried out using the Anates program. The results showed that $15 \%$ of the questions were in the good category, 67\% of the questions were in the good enough category, and $18 \%$ of the questions were in the bad category. So, it can be concluded that the items are suitable for use in the final school exam. The benefits that can be obtained from the results of this study are that it is better to always prepare reserve questions to replace the questions with a bad category, revisions can be made to the questions with a good enough category to be reused later, and the questions with a good category can be entered into the question bank.
\end{abstract}

Keywords: analysis, questions, anates program

How to Cite: Mania, S., Fitriani, Majid, A., F., Ichiana, N., N., \& Abrar, A., I., P. (2020). Analisis butir soal ujian akhir sekolah. Al asma: Journal of Islamic Education, 2(2), 274-284.

\section{PENDAHULUAN}

Berdasarkan Permendikbud Nomor 43 (2019) dijelaskan bahwa ujian yang diselenggarakan Satuan Pendidikan dan Ujian Sekolah (US) adalah penilaian dari hasil belajar yang dilakukan oleh satuan pendidikan yang bertujuan untuk melihat pencapaian 
standar kompetensi semua mata pelajaran yang dilulusi, baik bentuk ujian Satuan Pendidikan serta Ujian Sekolah berupa portofolio, penugasan, tes tertulis, dan bentuk lain yang ditetapkan dalam Satuan Pendidikan berdasarkan kompetensi yang diukur sesuai Standar Ujian Nasional Satuan Pendidikan. Adapun kriteria kelulusan siswa dari sekolah berdasarkan Permendikbud Nomor 43, (2019) pasal 6 adalah 1) telah menyelesaikan semua program mata pelajaran, 2) memperoleh penilaian sikap/perilaku minimal baik, 3) mengikuti setiap ujian yang dilaksanakan pada setiap mata pelajaran yang ada di sekolah. Mengacu pada kriteria di atas maka penilaian siswa tidak terlepas dari hasil evaluasi, pengukuran, dan tes berupa ujian sekolah yang merupakan salah satu penentu kelulusan.

Pada ujian sekolah, beberapa mata pelajaran pokok yang akan diujikan di antaranya Matematika, Bahasa Indonesia, Bahasa Inggris, dan IPA. Hasil dari evaluasi tersebut sangat diperlukan untuk melihat potensi dan kemampuan siswa pada mata pelajaran yang diberikan (Arifin, 2015). Untuk mengukur kemampuan siswa, guru memberikan tes kepada siswa yang dapat dipertanggung jawabkan dalam segi kelayakan, validitas, reliabilitas, ketafsiran, dan efektifitas butir soal yang meliputi tingkat kesukaran (kesulitan) dan daya pembeda soal. Untuk mengetahui tercapai tidaknya materi yang telah dipelajari, penjelasan yang diberikan oleh guru, dan daya serap yang dimiliki siswa dalam pembelajaran maka haruslah dilakukan evaluasi. Evaluasi merupakan penilaian kegiatan dan kemajuan belajar siswa secara berkala dalam bentuk ujian, praktikum, tugas dan pengamatan yang dilakukan oleh guru secara langsung (Hamzah, 2014). Hasil akhir dari suatu evaluasi bukan hanya untuk mengukur sampai mana tujuan pembelajaran itu tercapai tetapi hal tersebut juga akan digunakan untuk mengambil suatu keputusan (Arikunto, 2010). Jadi dari beberapa pengertian tersebut dapat ditarik kesimpulan bahwa evaluasi merupakan suatu kegiatan untuk memahami, menilai, dan mengukur potensi serta kemampuan siswa dalam mencapai tujuan pembelajaran sehingga dapat diperoleh suatu keputusan.

Seperti yang telah diuraikan sebelumnya bahwa evaluasi berkaitan erat dengan penilaian, pengukuran, dan tes. Alat evaluasi yang sering digunakan adalah tes (Wulan, 2001). Tes ialah suatu alat pengukuran/penilaian dalam bidang pendidikan, pengukuran/penilaian tersebut dapat berupa tugas baik itu suatu yang berbentuk pertanyaan atau perintah yang wajib dijawab dan diselesaikan oleh setiap siswa (Ismanto, 2014). Kemudian suatu keputusan dapat diambil berdasarkan hasil dari tes tersebut berupa nilai/prestasi dari siswa peserta tes. Selanjutnya nilai tersebut dapat diurutkan dengan melakukan perbandingan terhadap nilai yang diperoleh peserta tes lainnya atau dapat pula dibandingkan dengan kriteria ketuntasan minimal yang telah ditentukan sebelumnya. Tes tersebut berupa soal-soal dalam ujian sekolah dalam konstruksi soal pilihan ganda. Dalam pemberian soal-soal pilihan ganda tersebut perlu dievaluasi untuk untuk melihat kriterianya. Untuk melihat hasil kelemahan dan kekurangan tes dari soalsoal tesebut ada dua cara yaitu: 1) dengan analisis soal, 2) dengan menghitung validatas serta reliabilitas soal (Firmansyah \& Sridadi, 2018).

Sesuai dengan masalah ini akan dibahas tentang analisis soal, menurut Sudjana (Pasi \& Yusrizal, 2018) menyatakan bahwa analisis soal adalah telaah terhadap butir-butir soal dengan tujuan agar dapat menghasilkan suatu instrumen tes yang berkualitas. Setiap butir soal tersebut harus mencakup seluruh kurikulum, diharapkan kompetensi dasar dan standar kompetensinya tercapai, dengan dilaksanakannya analisis butir soal ini 
diharapkan dapat diperoleh hasil mengenai berfungsi atau tidaknya soal yang diberikan (Nuswowati dkk., 2011).

Tujuan penelaahan adalah untuk mengkaji dan menelaah setiap butir soal, sebab belum tentu semua butir soal dianggap layak untuk digunakan (Sumiati dkk., 2018). Penentuan revisi suatu butir soal tidak semata-mata berdasarkan besarnya indeks tingkat kesulitan dan daya beda soal melainkan sebaran distribusi frekuensi jawaban pada alternatif yang disediakan (Febriani, 2016). Dalam kegiatan menganalisis butir soal harus dilakukan oleh seorang guru atau sudah masuk dalam tim pembuat soal untuk meningkatkan kualitas soal yang telah dibuat. Menurut Zuriyanti dalam Fitrianawati (2015) dalam menganalisis butir soal ada manfaat yang perlu diperhatikan yaitu untuk menentukan soal-soal yang kurang dan tidak sesuai dengan penggunaannya, meningkatkan butir soal melalui 3 komponen analisis, serta meningkatkan pembelajaran melalui ambiguitas soal yang menyebabkan siswa merasa sulit dalam penyelesaian butir soal.

Analisis butir soal merupakan kegiatan menganalisis soal untuk mengidentifikasi soal-soal dalam suatu tes sehingga dapat dipergunakan (Nasir, 2015). Butir soal yang umumnya digunakan dalam ujian sekolah adalah soal pilihan ganda (Multiple Choice Question). Soal pilihan ganda (Multiple Choice Question) adalah soal yang memiliki beberapa alternatif jawaban. Pada umumnya soal pilihan ganda alternatif jawabannya berkisar 2 (Dua) sampai 5 (Lima) pilihan, apabila alternatif jawaban pada soal pilihan ganda lebih dari 5 (Lima) maka akan menyulitkan dalam penyusunan butir soal, dan membingungkan para siswa. Slamet \& Maarif, (2014) mengemukakan bahwa terdapat kelebihan dan kelemahan dalam soal pilihan ganda di antaranya:

1. Kelebihan soal pilihan ganda, soal yang mudah dianalisa, mencakup banyak materi, semua indikator terpenuhi, dapat mengukur kemampuan siswa sesuai domain yang dikehendaki sesuai dengan tingkat kesukarannya.

2. Kelemahan soal pilihan ganda, kurang menggambarkan suatu proses, hanya dapat mengetahui kemampuan kognitif, dapat menjawab soal tanpa harus menganalisa terlebih dahulu, tidak mampu menggambarkan kemampuan siswa secara utuh.

Sementara itu, berdasarkan hasil observasi diketahui bahwa hasil ujian akhir siswa yang dikenal memiliki kemampuan tinggi dan berprestasi memperoleh nilai yang lebih rendah dibandingkan dengan siswa yang kemampuannya masih di bawah rata-rata. Hal ini terlihat dari beberapa soal matematika yang diujikan pada ujian akhir sekolah terdapat soal-soal yang terlalu susah dan terlalu mudah. Hal ini sejalan dengan beberapa penelitian terdahulu yang dilakukan oleh Pasi \& Yusrizal, (2018) bahwa dari keseluruhan butir soal bahasa Indonesia kelas VIII buatan guru MTsN di kabupaten Aceh Besar tahun 2016/2017 termasuk kategori sedang. Hal ini menunjukkan bahwa semua guru bahasa Indonesia kelas VIII MTsN mampu membuat soal ujian dilihat dari segi validatas, reliabilitas, tingkat kesukaran, daya pembeda, dan efiktivitas pengecoh. Hal ini pula sejalan dengan penelitian yang dilakukan oleh Sappaile \& Pristiwaluyo, (2019) mengatakan bahwa kriteria validitas isi dan validitas internal telah memenuhi kriteria, unsur reliabilitas tes tidak memenuhi karena koefisien reliabilitasnya 0,561, daya pembeda pada kategori kurang baik dan sebagian besar pengecoh telah berfungsi efektif, tingkat kesukaran sebagian besar butir 
soal berada pada kategori sukar dan tebakan semua berada pada kategori baik, daya beda dari setiap butir soal dapat diamati pada kurva karakteristik masing-masing butir tes, dengan menggunakan analisis model 3PL daya butir tes. Supandi \& Farikhah (2016) menyatakan bahwa berdasarkan hasil analisis data kualitas soal memiliki validitas dan reliabilitas yang tinggi sedangkan dari tingkat kesukaran tergolong cukup, ini terlihat dari tingkat kesukaran soal sebesar $60 \%$ pada kategori mudah, $30 \%$ pada kategori sedang, dan $10 \%$ pada kategori sukar.

Oleh karena itu, dapat disimpulkan terdapat beberapa hal penting yang harus dikaji terkait analisis butir soal yang dibuat oleh guru. Berdasarkan permasalahan dan hasil penelitian terdahulu yang telah diuraikan di atas maka dalam penelitian ini akan membahas tentang analisis butir soal ujian akhir sekolah sehingga dapat diketahui kualitas dan kelayakan dari butir-butir soal tersebut untuk digunakan sebagai instrumen evaluasi.

\section{METODE PENELITIAN}

Penelitian ini menggunakan pendekatan kuantitatif, dengan jenis deskriptif kualitatif dan desain evaluasi dengan tujuan untuk mengetahui kualitas butir soal Ujian Akhir Sekolah (UAS) mata pelajaran matematika. Subjek penelitian ini adalah 159 siswa di SMAN 1 Pitumpanua Kabupaten Wajo. Pengumpulan data dilakukan melalui dokumentasi berupa lembar soal, kunci jawaban, dan lembar jawaban ujian akhir sekolah siswa. Data yang terkumpul kemudian dianalisis menggunakan aplikasi program Anates, antara lain untuk mengetahui daya pembeda, tingkat kesukaran, dan efektifitas pengecoh. Berikut ini adalah kriteria identifikasi tingkat kesukaran butir soal (Iskandar \& Rizal, 2017).

Tabel 1. Kriteria Tingkat Kesukaran Butir Soal

\begin{tabular}{cc}
\hline Nilai $\mathbf{P}$ & Interpretasi \\
\hline $\mathrm{P}=0,00$ & Sangat Sukar \\
$0,00<\mathrm{P} \leq 0,30$ & Sukar \\
$0,30<\mathrm{P} \leq 0,70$ & Sedang \\
$0,70<\mathrm{P}<1,00$ & Mudah \\
$\mathrm{P}=1,00$ & Sangat Mudah \\
\hline
\end{tabular}

Salah satu syarat instrumen tes yang baik harus melihat daya beda (diskriminasi). Daya beda suatu butir tes bertujuan untuk membedakan antara peserta tes yang berkemampuan tinggi dan berkemampuan rendah (Iskandar \& Rizal, 2017). Berikut ini tabel kriteria untuk daya pembeda butir soal.

Tabel 2. Kriteria Indeks Daya Pembeda Butir Soal

\begin{tabular}{cc}
\hline Nilai Dp & Interpretasi \\
\hline $\mathrm{Dp} \leq 0,00$ & Sangat jelek \\
$0,00<\mathrm{Dp} \leq 0,20$ & Jelek \\
$0,20<\mathrm{Dp} \leq 0,40$ & Cukup \\
$0,40<\mathrm{Dp} \leq 0,70$ & Baik \\
$0,70<\mathrm{Dp} \leq 1,00$ & Sangat Baik \\
\hline
\end{tabular}

Selain syarat daya beda juga harus memperhatikan efektivitas distractor (pengecoh). Setiap tes pilihan ganda memiliki satu pertanyaan serta beberapa pilihan jawaban. Efektivitas pengecoh adalah seberapa baik pilihan yang salah tersebut dapat 
mengecoh peserta tes yang memang tidak mengetahui kunci jawaban yang tersedia. Semakin banyak peserta tes yang memilih pengecoh tersebut, maka distaktor itu dapat menjalankan fungsinya dengan baik (Iskandar \& Rizal, 2017). Kriteria indeks pengecoh butir soal disajikan dalam tabel berikut.

Tabel 3. Kriteria Indeks Pengecoh Butir Soal

\begin{tabular}{cc}
\hline Nilai IP & Interpretasi \\
\hline$>200 \%$ & Sangat jelek \\
$0 \%-25 \%$ atau $176 \%-200 \%$ & Jelek \\
$26 \%-50 \%$ atau $151 \%-175 \%$ & Kurang Baik \\
$51 \%-75 \%$ atau $126 \%-150 \%$ & Baik \\
$76 \%-125 \%$ & Sangat Baik \\
\hline
\end{tabular}

Selanjutnya berdasarkan beberapa pertimbangan dapat ditentukan kualitas dari soal-soal yang telah dianalisis antara lain soal dengan kualitas baik, cukup baik, dan tidak baik. Beberapa pertimbangan yang dimaksud adalah: a) jika butir soal memenuhi ketiga kriteria yaitu kriteria tingkat kesukaran, daya pembeda, dan keefektifan pengecoh maka butir soal tersebut memiliki kualitas baik, b) jika hanya memenuhi dua kriteria maka butir soal tersebut memiliki kualitas cukup baik, dan c) jika tidak memenuhi ketentuan a dan b tersebut maka butir soal memiliki kualitas yang tidak baik.

\section{HASIL DAN PEMBAHASAN}

Adapun tujuan dari penelitian ini untuk mengetahui tentang hasil ujian akhir sekolah siswa, dari hasil penelitian tersebut diperoleh beberapa data dalam bentuk dokumen di antaranya daftar hadir peserta ujian akhir sekolah, soal yang diujikan, kunci jawaban, dan lembar jawaban siswa peserta ujian. Soal ujian berbentuk pilihan ganda (multiple choice question) sebanyak 40 butir soal. Aplikasi Anates digunakan untuk menganalisis data yang terkumpul dengan tujuan untuk mengetahui kualitas butir soal ujian akhir mata pelajaran matematika.

\section{Tingkat Kesukaran Soal Ujian Akhir Sekolah}

Tingkat kesukaran soal ujian akhir sekolah merupakan peluang bagi siswa untuk menjawab benar pada setiap butir soal baik yang memiliki tingkat kesukaran yang sedang, sukar maupun sangat sukar.

Tabel 4. Hasil Analisis Tingkat Kesukaran Soal UAS

\begin{tabular}{cccc}
\hline No. & Kategori & Butir Soal & Jumlah \\
\hline 1. & Sangat Sukar & $10,11,13,18,33,34,36,37$ & 8 \\
2. & Sukar & $6,14,20,22,25,27,28,29,32$ & 9 \\
3. & Sedang & $1,4,8,19,23,24,30,31,35,38,40$ & 11 \\
4. & Mudah & $3,7,12,15,16,17,21,26$ & 8 \\
5. & Sangat Mudah & $2,5,9,39$ & 4 \\
\hline
\end{tabular}




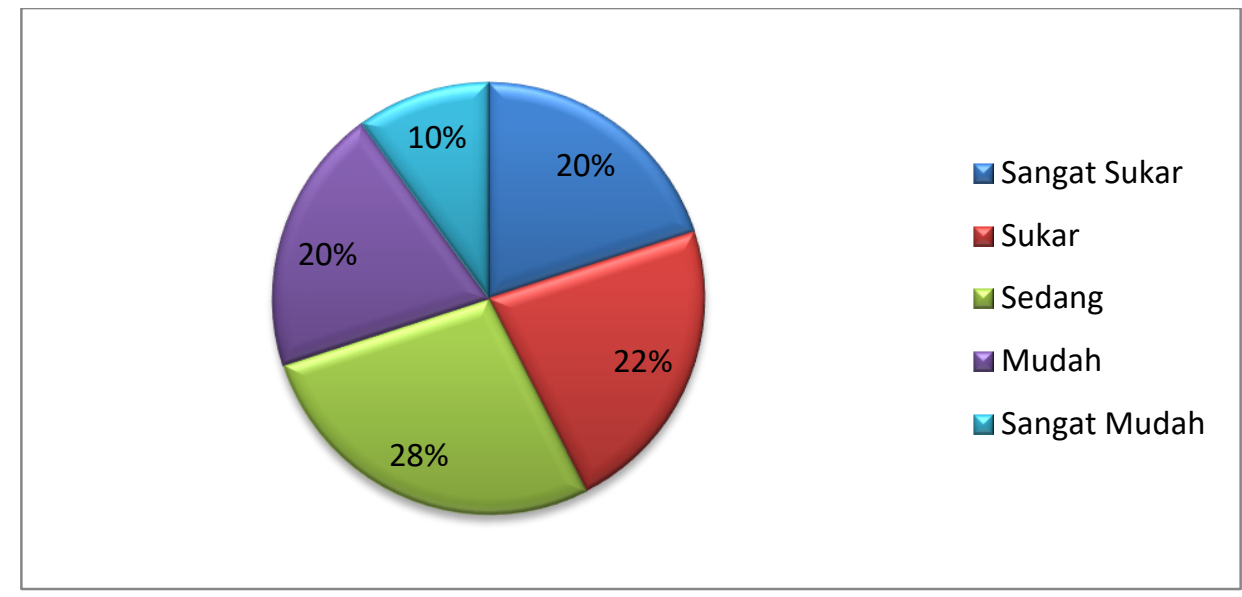

Gambar 1. Persentase Tingkat Kesukaran Soal UAS

Pada tabel 4 dan gambar 1, diperoleh hasil yang menunjukkan sebanyak $28 \%$ butir soal ujian berada di kategori sedang, $22 \%$ berada di kategori sukar, $20 \%$ butir soal berada di kategori sangat sukar, $20 \%$ butir soal berada di kategori mudah dan $10 \%$ butir soal berada di kategori sangat mudah. Hasil penelitian hampir sama dengan yang dilakukan oleh Febriani, (2016) yang menyatakan bahwa dari 40 butir soal 19 diantaranya atau sekitar 47,5\% tidak layak untuk digunakan untuk ujian selanjutnya.

Berdasarkan indeks tingkat kesukaran, soal yang berkategori sedang merupakan soal dengan tingkat kesukaran seimbang, butir soal yang tergolong dalam kategori sangat sukar bejumlah 8 butir soal yaitu soal nomor 10, 11, 13, 18, 33, 34, 36, dan 37. Indeks soalsoal ini terdapat pada rentang $P=0,00$ sehingga butir soal-soal ini sebaiknya tak perlu digunakan kembali pada tes-tes selanjutnya. Soal yang terlalu sulit dapat menghilangkan semangat dan motivasi siswa atau peserta tes dalam menyelesaikan soal tersebut karena di luar kemampuannya sedangkan soal yang terlalu mudah tidak akan merangsang siswa untuk berpikir sehingga soal yang baik itu adalah yang sesuai dengan kemampuan siswa serta tidak terlalu sulit ataupun terlalu mudah dalam hal ini berkategori sedang (Halik et al., 2019). Oleh karena itu untuk butir soal nomor 1, 4, 8, 19, 23, 24, 30, 31, 35, 38, dan 40 dengan kategori sedang dapat digunakan kembali untuk ujian yang akan datang. Untuk butir soal yang berkategori mudah ada baiknya untuk diteliti kembali untuk mengetahui penyebab soal tersebut dapat dengan mudah dikerjakan oleh peserta tes, dan dengan mudahnya para peserta menemukan mana kunci jawaban dan yang mana hanya sebuah pengecoh. Dari uraian di atas dapat diketahui bahwa kualitas butir soal berdasarkan tingkat kesukaran termasuk dalam soal yang kurang baik.

2. Daya pembeda soal Ujian Akhir Sekolah

Daya pembeda adalah kemampuan soal untuk membedakan siswa yang berkemampuan tinggi dan berkemampuan rendah.

Tabel 5. Hasil Analisis Daya Pembeda Soal UAS

\begin{tabular}{cccc}
\hline No. & Kategori & Butir Soal & Jumlah \\
\hline 1. & Sangat Jelek & $8,10,22,24,25,33,34,36$ & 8 \\
2. & Jelek & $7,9,13,27,35$ & 5 \\
3. & Cukup & $2,4,5,11,12,15,17,18,20,28,37$ & 11 \\
4. & Baik & $1,3,14,16,19,21,23,26,29,30,31,32,39,40$ & 14 \\
5. & Sangat Baik & 6,38 & 2 \\
\hline
\end{tabular}




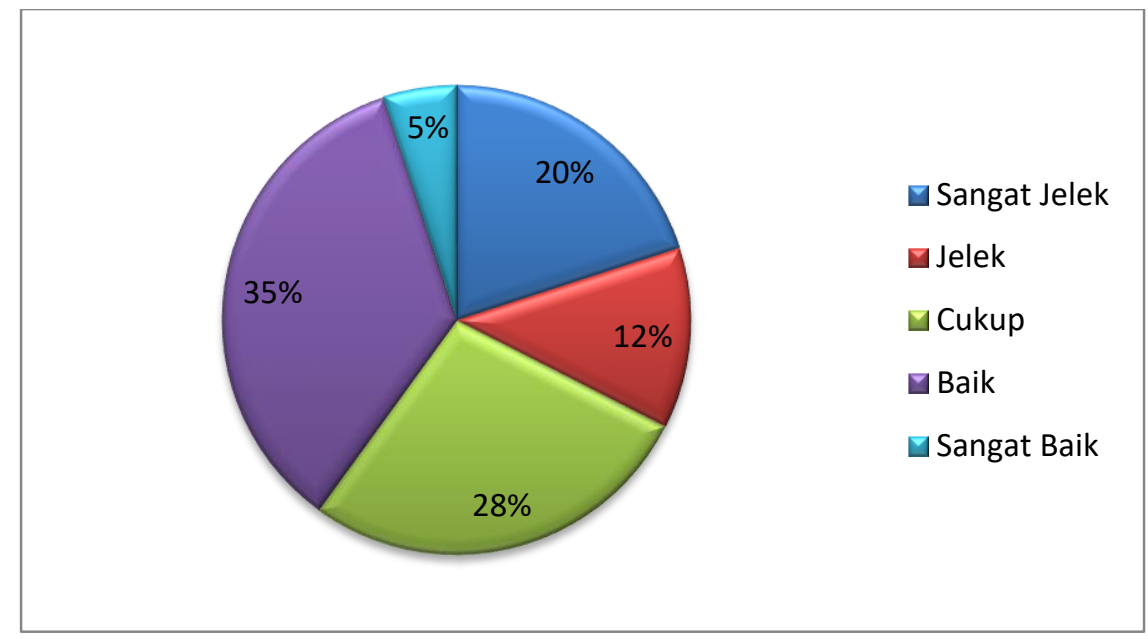

Gambar 2. Persentase Daya Pembeda Soal UAS

Berdasarkan tabel 5 dan gambar 2 di atas terlihat bahwa 8 butir soal atau sekitar $20 \%$ berada pada kategori sangat jelek, 5 butir soal atau sekitar $12 \%$ berada pada kategori jelek, 11 butir soal atau sekitar 28\% berada pada kategori cukup, 14 butir soal atau sekitar $35 \%$ berada pada kategori baik, dan 2 butir soal atau sekitar 5\% berada pada kategori sangat baik. Hal ini juga sejalan dengan penelitian yang dilakukan oleh Pasi \& Yusrizal, (2018) bahwa daya pembeda soal yang disusun oleh guru MTsN di kabupaten Aceh Besar di antaranya: MTsN Tungkob yang berada pada kategori baik, MTsN Jeureula 67\% berada pada kategori baik, 33\% berada pada kategori jelek, Guru Montasik 40\% berada pada kategori cukup dan 60\% berada pada kategori tidak cukup, Guru MTsN Cot Gue 50\% berada pada kategori baik, dan $50 \%$ berada pada kategori tidak baik.

Berdasarkan simpulan kualitas soal dilihat dari daya pembeda yaitu terdapat soal berada pada kategori baik atau sangat baik. Butir soal yang dikatakan baik dan sangat baik itu berjumlah 14 butir soal baik yaitu nomor 1, 2, 14, 16, 19, 21, 23, 26, 29, 30, 31, 32, 39 , dan 40 serta 2 butir soal sangat baik yaitu butir soal nomor 6 dan 38. Butir-butir soal ini dapat digunakan dan dimasukkan ke dalam bank soal.

Untuk butir soal dengan kategori cukup berdasarkan daya pembeda adalah butir soal yang masih dapat membedakan siawa yang paham dengan materi dan siswa yang tidak paham pada materi. Pada butir soal kategori cukup dapat menyebabkan siswa yang belum mengerti pada materi bisa secara kebetulan menebak jawaban yang benar. Butir soal cukup dapat digunakan kembali jika soal tersebut telah direvisi atau diperbaiki dan disimpan dalam bank soal. Sedangkan butir soal dengan kategori jelek dan sangat jelek berdasarkan daya pembeda adalah soal yang tidak dapat membedakan siswa yang menguasai dan yang tidak menguasai materi. Butir soal dalam kategori jelek dan sangat jelek sebaiknya tidak perlu digunakan lagi dan digantikan dengan soal yang baru.

3. Hasil Analisis Efektifitas Opsi Soal Ujian Akhir Sekolah

Hasil analisis yang diperoleh pada penelitian ini merupakan karakteristik untuk menentukan kualitas sebuah soal. 
Tabel 6. Hasil Analisis Efektifitas Opsi Soal UAS

\begin{tabular}{cccc}
\hline No. & Kategori & Butir Soal & Jumlah \\
\hline 1. & Sangat Baik & $28,30,32,33,34,35$, & 6 \\
2. & Baik & $10,11,13,18,19,22,25,26,27,31,36,37,40$ & 13 \\
3. & Kurang Baik & $1,2,3,4,6,8,14,15,16,17,21,24,29,38$ & 14 \\
4. & Jelek & $5,7,9,12,20,23,39$ & 7 \\
5. & Sangat Jelek & - & 0 \\
\hline
\end{tabular}

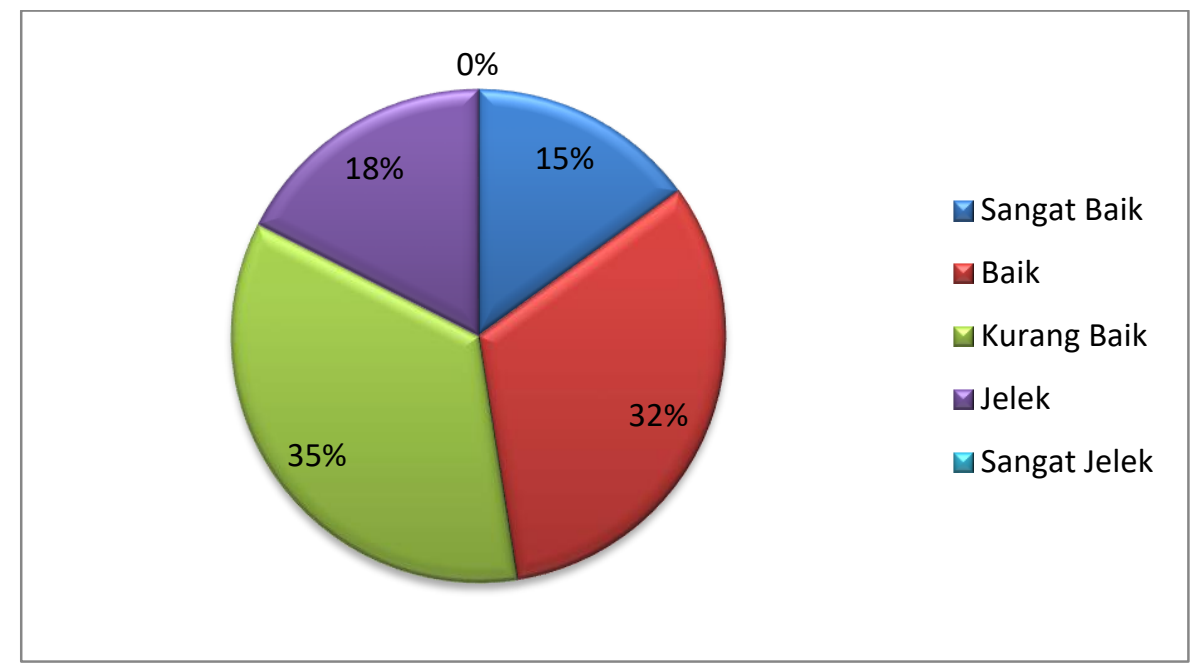

Gambar 3. Persentase Efektifitas Opsi Soal UAS

Dari tabel 6 dan gambar 3 di atas menujukkan bahwa 6 butir soal dengan persentase $15 \%$ dalam kategori sangat baik, 13 butir soal dengan persentase $32 \%$ dalam kategori baik, 14 butir soal dengan persentase 35\% dalam kategori kurang baik, 7 butir soal dengan tingkat persentase $18 \%$ dalam kategori jelek dan tidak ada butir soal dalam kategori sangat jelek atau berada pada persentase $0 \%$.

Butir soal nomor 28, 30, 32, 33, 34, dan 35 serta butir soal nomor 10, 11, 13, 18, $19,22,25,26,27,31,36,37$, dan 40 merupakan butir soal yang sangat baik dan baik. Hal ini berarti opsi pengecoh pada butir-butir soal tersebut memiliki peluang yang besar untuk dipilih oleh peserta tes. Dengan demikian butir-butir soal tersebut dapat dimasukkan pada bank soal untuk dipergunakan pada tes atau ujian lainnya. Untuk butir soal nomor 5, 7, 9, 12, 20, 23, dan 39 termasuk dalam kategori butir soal yang jelek sehingga butir soal ini tidak perlu digunakan lagi.

Berdasarkan pemaparan di atas dapat disimpulkan bahwa salah satu syarat soal dikatakan baik jika soal tersebut tersebut memiliki kualitas pengecoh yang baik pula. Butir soal dikatakan baik jika opsi pengecohnya memiliki peluang yang sama untuk dipilih oleh peserta tes (Sulistiawan, 2016). Sebaliknya jika opsi pengecohnya tidak memiliki peluang yang sama untuk dipilih maka butir soal pilihan ganda tersebut dapat dikatakan kurang baik.

4. Distribusi Butir Soal Ujian Akhir Sekolah Mata Pelajaran Matematika

Distribusi butir soal dilakukan untuk mengetahui kualitas dari masing-masing butir soal yaitu butir soal yang berkualitas baik, cukup baik, dan tidak baik. Hal ini dapat dilakukan dengan menganalisis data hasil tingkat kesukaran, daya pembeda, dan 
efektifitas opsi yang telah didapatkan sebelumnya. Data distribusi butir soal disajikan dalam tabel berikut

Tabel 7. Distribusi Butir Soal UAS Mata Pelajaran Matematika

\begin{tabular}{cccc}
\hline No. & Kategori & Butir Soal & Jumlah \\
\hline 1. & Baik & $19,26,30,31,32,40$ & 6 \\
2. & Cukup Baik & $1,2,3,4,6,8,11,12,13,14,15,16,17,18,20,21,22,23$, & 27 \\
3. & Tidak Baik & $24,25,27,28,29,35,37,38,39$ & 7 \\
\hline
\end{tabular}

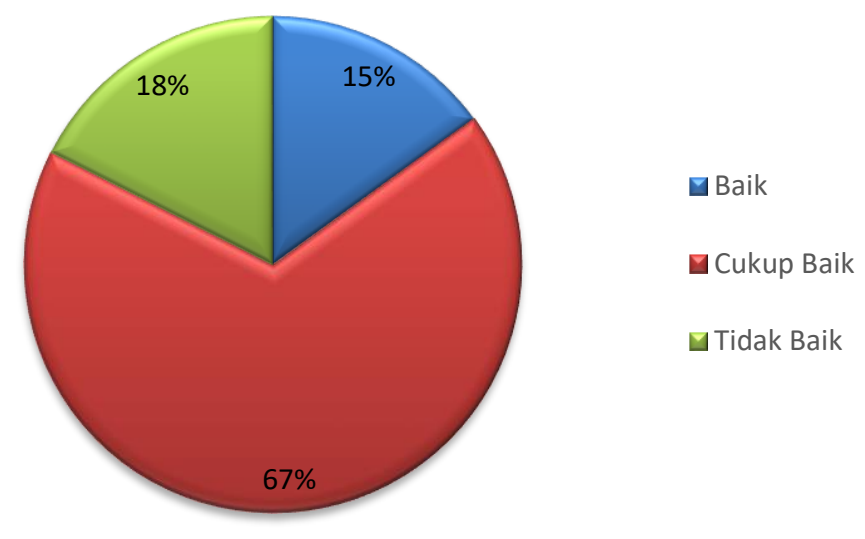

Gambar 4. Persentase Distribusi Butir Soal UAS Mata Pelajaran Matematika

Berdasarkan tabel 7 dan gambar 4 di atas terlihat bahwa dari 40 butir soal, 6 butir soal atau sekitar $15 \%$ butir soal berada pada kategori baik, 27 butir soal atau sekitar $67 \%$ berada pada kategori cukup baik, dan 7 butir soal lainnya berada pada kategori tidak baik atau dengan jumlah presentase 18\%. Sehingga sebanyak 33 butir soal dengan kategori baik dan cukup baik, olehnya itu sudah layak untuk digunakan dalam ujian akhir sekolah.

Dari data yang telah diperoleh di atas dapat diketahui bahwa kualitas butir soal merupakan faktor yang sangat penting dalam menyusun suatu instrumen tes. Olehnya itu analisis terhadap kualitas butir soal perlu dilakukan untuk mengetahui kelayakan suatu butir soal yang akan digunakan dalam tes atau dalam penelitian ini adalah ujian akhir sekolah.

\section{SIMPULAN}

Berdasarkan hasil dan pembahasan di atas maka dapat ditarik suatu kesimpulan bahwa analisis butir soal ujian akhir sekolah di SMA 1 Pitumpanua yang melibatkan sekitar 159 orang siswa menunjukkan kualitas yang baik dan kelayakan dari setiap butir soal untuk digunakan sebagai instrumen evaluasi. Hal ini terlihat dari hasil analisis data yang dilakukan dengan menggunakan program Anates dimana $82 \%$ atau 33 butir soal dari 40 butir soal yang terdiri dari 6 butir soal atau 15\% berada pada kategori baik dan 27 butir soal atau $67 \%$ berada pada kategori cukup baik sehingga butir-butir soal tersebut telah layak digunakan dalam ujian akhir sekolah.

\section{DAFTAR PUSTAKA}

Arifin, Z. (2015). Evaluasi pembelajaran. Jakarta: Direktorat Jenderal Pendidikan Islam Kementerian Agama RI. 
Arikunto, S. (2010). Dasar-dasar evaluasi pendidikan. Jakarta: Bumi Aksara.

Febriani, I. M. (2016). Analisis butir soal Ujian Akhir Semester (UAS) bahasa jerman kelas X MIA 6 SMA Negeri 1 Maospati Tahun Pelajaran 2015/2016. Laterne, V(2), 1-12.

Firmansyah, H., \& Sridadi. (2018). Analisis butir soal tes pilihan ganda mata pelajaran pendidikan jasmani olahraga dan kesehatan kelas VIII SMPN 1 Wonosari Tahun Ajaran 2017/2018. Pendidikan Jasmani Kesehatan Dan Rekreasi, 7(12), 139-157.

Fitrianawati, M. (2015). Peran analisis butir soal guna meningkatkan kualitas butir soal, kompetensi guru dan hasil belajar peserta didik. Prosiding Seminar Nasional Pendidikan PGSD UMS \& HDPGSDI Wilayah Jawa, 5(3), 282-295.

Halik, A. S., Mania, S., \& Nur, F. (2019). Analisis butir soal Ujian Akhir Sekolah (UAS) mata pelajaran matematika pada tahun ajaran 2015/2016 SMP Negeri 36 Makassar. Journal of Islamic Education, Vol. 1(No. 1), 11-17.

Hamzah, A. (2014). Evaluasi pembelajaran matematika (Cetakan ke-1). Jakarta: PT RajaGrafindo.

Iskandar, A., \& Rizal, M. (2017). Analisis kualitas soal di perguruan tinggi berbasis aplikasi TAP. Jurnal Penelitian dan Evaluasi Pendidikan, 21(2), 12-23.

Ismanto, I. (2014). Evaluasi hasil belajar Pendidikan Agama Islam (PAI). Edukasia : Jurnal Penelitian Pendidikan Islam, 9(2), 211-236. https://doi.org/10.21043/edukasia.v9i2.773

Kementerian Pendidikan dan Kebudayaan. (2019). Peraturan Menteri Pendidikan Dan Kebudayaan Republik Indonesia Nomor 43 Tahun 2019 tentang Penyelenggaraan Ujian yang Diselenggarakan Satuan Pendidikan dan Ujian Nasional. Jakarta: Kementerian Pendidikan Dan Kebudayaan.

Nasir, M. (2015). Analisis empirik program analisis butir soal dalam rangka menghasilkan soal yang baik dan bermutu sebagai alat evaluasi pembelajaran fisika. Prosiding Semirata, 336-347.

Nuswowati, M., Binadja, A., Soeprodjo, \& Ifada, K. E. N. (2011). Pengaruh validitas dan reliabilitas butir soal ulangan akhir semester bidang studi kimia terhadap pencapaian kompetensi. Jurnal Inovasi Pendidikan Kimia, 4(1), 566-573.

Pasi, S. N., \& Yusrizal. (2018). Analisis butir soal ujian bahasa indonesia buatan guru MTsN di Kabupaten Aceh Besar. Master Bahasa, 6(2), 195-202. http://www.jurnal.unsyiah.ac.id/MB/article/view/11666

Sappaile, B. I., \& Pristiwaluyo, T. (2019). Analisis butir soal ujian sekolah berstandar nasional dengan pendekatan klasik dan teori respon butir mata pelajaran matematika. Proceedings of National Seminar Research and Community Service Institue Universitas Negeri Makassar, 15, 246-253.

Slamet, S., \& Maarif, S. (2014). Pengaruh bentuk tes formatif assosiasi pilihan ganda dengan reward dan punishment score pada pembelajaran matematika siswa SMA. Infinity Journal, 3(1), 59-80. https://doi.org/10.22460/infinity.v3i1.39

Sulistiawan, C. H. (2016). Kualitas soal ujian sekolah matematika program ipa dan kontribusinya terhadap hasil ujian nasional. Jurnal Penelitian Dan Evaluasi Pendidikan, 20(1), 1-10. https://doi.org/10.21831/pep.v20i1.7516

Sumiati, A., Widiastuti, U., \& Suhud, U. (2018). Workshop teknik menganalisis butir soal dalam meningkatkan kompetensi guru di SMK Cileungsi Bogor. Jurnal 
Pemberdayaan Masyarakat Madani (JPMM), 2(1), 136-153. https://doi.org/10.21009/jpmm.002.1.10

Supandi, S., \& Farikhah, L. (2016). Analisis butir soal matematika pada instrumen uji coba materi segitiga.JIPMat, 1(1), 71-78. https://doi.org/10.26877/jipmat.v1i1.1085

Wulan, A. R. (2001). Pengertian dan esensi konsep evaluasi, asesmen, tes, dan pengukuran. FMIPA Universitas Pendidikan Indonesia, 1-12. 